\title{
Substrate uptake and utilization by a marine ultramicrobacterium
}

\author{
Frits Schut, $†$ Michel Jansen, Teresa M. Pedro Gomes, Jan C. Gottschal, \\ Wim Harder and Rudolf A. Prins
}

Author for correspondence: Frits Schut.e-mail: f.schut@med.rug.nl

Department of

Microbiology, University of

Groningen, PO Box 14, 9750

AA Haren, The Netherlands

\begin{abstract}
A facultatively oligotrophic ultramicrobacterium (strain RB2256) isolated from an Alaskan fjord by extinction dilution in seawater, was grown in batch culture and under single- and dual-substrate-limitation of alanine and glucose in a chemostat. The nature of the uptake systems, and the uptake kinetics and utilization patterns of alanine and glucose were investigated. Glucose uptake was inducible, the system exhibited a narrow substrate specificity, and part of the uptake system was osmotic-shock-sensitive. Half-saturation constants for glucose were between 7 and $74 \mu \mathrm{M}$ during glucose limitation. The initial step in glucose metabolism was the synthesis of sugar polymers, even during glucose-limited growth. The alanine uptake system was constitutively expressed and was binding-protein-dependent. In addition to L-alanine, nine other amino acids inhibited accumulation of $\left[{ }^{14} \mathrm{C}\right] \mathrm{L}$-alanine, indicating broad substrate specificity of the alanine transporter. Half-saturation constants between 1.3 and $1.8 \mu \mathrm{M}$ were determined for alanine uptake during alanine limitation. Simultaneous utilization of glucose and alanine occurred during substrate-limited growth in the chemostat, and during growth in batch culture at relatively high ( $\mathrm{mM}$ ) substrate concentrations. However, the half-saturation constant for alanine transport during dual-substrate-limitation, i.e. in the presence of glucose, increased almost fivefold. We conclude that mixed substrate utilization is an inherent property of this organism.
\end{abstract}

Keywords: oligotrophy, ultramicrobacteria, glucose, alanine, uptake systems

\section{INTRODUCTION}

The marine ecosystem is an oligotrophic environment where concentrations of low- $M_{\mathrm{r}}$ carbon compounds are commonly in the nanomolar range (Billen et al., 1980; Eguchi \& Ishida, 1990; Poulet et al., 1987; Münster, 1993). The organic carbon fluxes have been considered too low to support sustained growth of bacteria (Poindexter, 1981; Morita, 1988), and continuous nutrient deprivation is thought to result in a so-called starvationsurvival response of most micro-organisms (Morita, 1990). However, the low steady-state substrate concentrations may partly be due to the uptake activity of the bacteria themselves; in the euphotic zone of the open ocean, growth of bacterioplankton occurs with generation

\footnotetext{
†Present address: Department of Medical Microbiology, University of Groningen, PO Box 30.001, 9700 RB Groningen, The Netherlands.

Abbreviations: CCCP, carbonyl cyanide m-chlorophenylhydrazone; DCCD, $N, N^{\prime}$-dicyclohexylcarbodi-imide.
}

times of approximately $12 \mathrm{~h}$ (Sieburth et al., 1977; Karl, 1979; Carlucci \& Williams, 1978).

Although several studies have shown that unamended seawater is a suitable growth medium for naturally occurring bacteria (Jannasch, 1967; Ammerman et al., 1984; Hagström et al., 1984; Li \& Dickie, 1985; Schut et al., 1993), the possibility that significant alterations in its nutritional composition occur during experimental handling cannot be excluded (Ferguson et al., 1984). The results of such growth experiments therefore provide no real evidence for the occurrence of growth under natural conditions. However, the mere presence of $10^{\mathbf{5}}$ $10^{6}$ bacteria $\mathrm{ml}^{-1}$ in oceanic waters provides in itself a sufficient reason to believe that such organisms may have developed the ability to multiply under the prevailing conditions. Non-differentiating heterotrophic bacteria from these environments are thought to thrive under such oligotrophic conditions as a result of their unique substrate-sequestering abilities (Poindexter, 1981; Button, 1991). Against this background, the high specific 
substrate affinities of oligobacteria are thought to be significant (Button, 1991, 1993). Indeed, low $K_{\mathrm{t}}$ uptake systems have been found in marine isolates (Hamilton $e t$ al., 1966; Geesey \& Morita, 1979; Akagi \& Taga, 1980; Nissen et al., 1984). However, the reported $V_{\max }$ values are generally so low that specific affinities and oligotrophic capacities (Button, 1993) are insufficient to allow realistic generation times in the ocean at the expense of a single substrate. When consumed simultaneously, however, the ambient level of substrates could provide bacteria with enough carbon and energy for growth at more realistic rates. The ability to utilize multiple substrates simultaneously is a common trait of most known bacterial species, provided that the substrates are present at growthrate-limiting concentrations (Harder \& Dijkhuizen, 1982; Gottschal et al., 1992). This indicates metabolic regulation by derepression of uptake and utilization pathways. In the marine Pseudomonas sp. strain T2, the presence of amino acids can enhance the uptake of glucose and lower the threshold concentrations for growth (Law \& Button, 1977). Organisms able to grow in the open ocean would thus ideally exhibit simultaneous multiple substrate utilization abilities and a broad substrate spectrum. Data in the literature are not conclusive regarding the substrate spectrum of oligotrophic bacteria, since both broad (Upton \& Nedwell, 1989) and narrow (Eguchi \& Ishida, 1990) substrate utilization spectra have been reported and discussed as being advantageous for oligotrophic bacteria. Transporter specificity may indeed generally be lower in oligotrophs (Akagi \& Taga, 1980).

In a previous paper (Schut $e$ al., 1993), we reported the isolation of a facultatively oligotrophic ultramicrobacterium from seawater. This organism exhibited no increase in cell size upon isolation, and is thus a natural ultramicrobacterium. We found specific uptake affinities for mixed amino acids, but not for alanine or glucose alone, that would allow for realistic in situ generation times during growth on mixtures of amino acids. In this contribution we report a detailed study of the substrate utilization of this organism during single as well as dual carbon- and energy-limited growth in a chemostat. Furthermore we have characterized the uptake systems of both L-alanine and D-glucose. These two uptake systems have markedly different characteristics with respect to substrate specificity.

\section{METHODS}

Source of organism and culturing conditions. Ultramicrobacterium strain RB2256 was isolated from an Alaskan fjord as described previously (Schut et al., 1993). The organism is a Gram-negative, obligately aerobic, yellow-pigmented and flagellated rod. It is catalase- and oxidase-positive. Its mean cell volume of $0.06 \mu^{3}$ (dimensions $0.3 \mu \mathrm{m} \times 1.0 \mu \mathrm{m}$; see Schut $e$ t al., 1993) is characteristic of an ultramicrobacterium. On the basis of the 16S rRNA gene sequence, strain RB2256 belongs to the $\alpha$-proteobacterial lineage and is phylogenetically closely related to the genus Sphingomonas (Yabuuchi et al., 1990) and to Caulobacter subvibrioides, Porphyrobacter neustonensis and Erythrobacter longus (unpublished data). The organism was cultured in MPM medium as described previously (Schut $e t$ al., 1993), at
$\mathrm{pH} 7.8$ and $30^{\circ} \mathrm{C}$ with $2 \mathrm{mM}$ D-glucose, $4 \mathrm{mM}$ L-alanine, or $1 \mathrm{mM}$ D-glucose plus $2 \mathrm{mM} \mathrm{L}$-alanine as the carbon and energy sources (144 $\mathrm{mg}_{\text {carbon }} \mathbf{1}^{\mathbf{1}}$ ).

Analytical procedures. For residual substrate determination, samples from steady-state (at least 5 vol. changes) continuous cultures were filtered within 5-10 s through a $0 \cdot 2 \mu \mathrm{m}$ pore size membrane filter (BA 83; Schleicher \& Schuell), and the filtrate was frozen until analysis. Amino acids were analysed after 0 phthaldialdehyde derivatization by reversed-phase HPLC, using an Absorbosphere HS opa $5 \mu \mathrm{m}$ column (Alltech/Applied Science) at room temperature. Running buffer A contained glacial acetic acid $(0.3 \%, \mathrm{v} / \mathrm{v}, \mathrm{pH} 5.9)$ and tetrahydrofuran $(1 \%, v / v)$, and running buffer $B$ was composed of methyl cyanide $(10 \%, v / v)$ in methanol (HPLC grade). Samples were run with a mixture of buffer $A$ and $B(3: 1)$ and eluted by applying a gradient of $25 \%-80 \%$ buffer $B$ over a period of 30 min. D-Glucose was determined enzymically using standard kits (Boehringer Mannheim) with detection of NADH at $340 \mathrm{~nm}$. Protein was determined by the Lowry method using BSA as a standard. Organic carbon was determined on a Shimadzu TOC-500 analyser (Shimadzu Benelux) with sodium biphthalate as a standard.

Oxygen consumption rates. Substrate-dependent maximum specific oxygen consumption rates $\left(Q_{\mathrm{O}_{2}}^{\max }\right.$ values) were determined in a YSI Biological Oxygen Monitor (Yellow Springs Instruments). Cells were harvested by centrifugation for $10 \mathrm{~min}$ at 12000 r.p.m. and $4{ }^{\circ} \mathrm{C}$. After washing in MPM basal salts buffer, pH 7.8 (Schut et al., 1993), cells were resuspended to a final protein concentration of approximately $130 \mu \mathrm{g} \mathrm{ml}^{-1}$. Maximum specific oxygen consumption rates were determined at saturating concentrations of growth substrate $(1 \mathrm{mM})$. Cells were kept on ice until use, and measurements were performed within $15 \mathrm{~min}$. Comparison of twice-washed cell suspensions with samples taken directly from substrate-saturated batch cultures indicated that the processing protocol did not significantly affect oxygen consumption rates. Required specific oxygen utilization rates $\left(q_{\mathrm{o}_{2}}\right.$, req $)$, needed for complete oxidation of utilized substrate, were calculated by multiplying substrate utilization rates in culture ( $q_{\mathrm{s}}$ values) by the respiration stoichiometry $\left[3.6 \mathrm{~mol} \mathrm{O}_{2}(\mathrm{~mol} \text { glucose })^{-1} ; 2.1 \mathrm{~mol} \mathrm{O}_{2}(\mathrm{~mol}\right.$ alanine) $)^{-1}$.

Uptake experiments. Cells were harvested by centrifugation, washed twice in MPM basal salts buffer, resuspended ( $2 \mathrm{mg}$ protein $\mathrm{ml}^{-1}$ ) in MPM basal salts buffer and stored on ice until measurement. Immediately prior to uptake, $100 \mu \mathrm{l}$ aliquots of 10 -fold diluted cell suspensions in MPM basal salts buffer were energized with $10 \mu \mathrm{M}$ of L-alanine or D-glucose for $2 \mathrm{~min}$ at $30^{\circ} \mathrm{C}$, as described previously (Schut $e t$ al., 1993). Uptake rates in the first $30 \mathrm{~s}$ after addition of the labelled substrate were determined over a concentration range of $40 \mathrm{nM}-100 \mu \mathrm{M}$ substrate. For uptake inhibition (i.e. the effect of protonophores, etc.) and substrate specificity studies, cells were preincubated with $10 \mathrm{mM}$ ascorbate and $100 \mu \mathrm{M}$ PMS (phenazine methosulphate) for $1 \mathrm{~min}$ at $30^{\circ} \mathrm{C}$ (see Schut et al., 1993). The substrate specificity of the uptake systems was determined by incubating washed cell suspensions $\left(200 \mu \mathrm{g}\right.$ protein $\left.\mathrm{ml}^{-1}\right)$ with $1 \mu \mathrm{M} \mathrm{L}_{-}\left[\mathrm{U}_{-}{ }^{14} \mathrm{C}\right]$ alanine $\left(174 \mathrm{mCi} \mathrm{mmol}^{-1}\right)$ or $8 \mu \mathrm{M} \mathrm{D}-[\mathrm{U}-$ ${ }^{14} \mathrm{C}$ glucose $\left(144 \mathrm{mCi} \mathrm{mmol}^{-1}\right)$ in the presence of 10 -fold excess unlabelled test substrate at $30^{\circ} \mathrm{C}$.

Production of carbon dioxide during substrate uptake. This was determined by a modification of the method of Hobbie \& Crawford (1969). Aliquots $(100 \mu \mathrm{l})$ of a washed cell suspension of chemostat-grown cells $\left(200 \mu \mathrm{g}\right.$ protein $\left.\mathrm{ml}^{-1}\right)$ were added to a small glass tube containing a stirring bar. An accordion-folded piece of blotting paper (GB 002, Schleicher and Schuell) 
$(5 \times 2 \mathrm{~cm})$ was subsequently inserted into the neck of the tube. The tube was closed with a Subaseal septum through which additions to the cells were made. The uptake reaction was started by adding ${ }^{14} \mathrm{C}$-labelled substrate to the cells $\left[3 \mu \mathrm{M} \mathrm{L}_{\mathrm{L}}\right.$ $\left[\mathrm{U}^{14} \mathrm{C}\right.$ ]alanine $\left(17 \cdot 4 \mathrm{mCi} \mathrm{mmol}^{-1}\right)$ or $2 \mu \mathrm{M}$ - $\left[\mathrm{U}^{14} \mathrm{C}\right]$ glucose $\left.\left(2.9 \mathrm{mCi} \mathrm{mmol}^{-1}\right)\right]$, and was stopped by quickly adding $4 \%$ (v/v) formaldehyde and $1 \%(\mathrm{v} / \mathrm{v}) \mathrm{H}_{2} \mathrm{SO}_{4}$. Approximately $100 \mu \mathrm{l}$ Carbosorb was added to the blotting paper, again through the septum, after which the tubes were left sealed for another $30 \mathrm{~min}$. The accumulation of ${ }^{14} \mathrm{C}$-label in both the blotting paper and the filtered cells was measured.

Incorporation of labelled substrate into macromolecules. Samples containing $200 \mu \mathrm{l}$ of a washed cell suspension $(0.2 \mathrm{mg}$ protein $\mathrm{ml}^{-1}$ ) were incubated at $30^{\circ} \mathrm{C}$ with $3 \mu \mathrm{M} \mathrm{L}-\left[\mathrm{U}_{-}{ }^{14} \mathrm{C}\right]-$ alanine $\left(17.4 \mathrm{mCi} \mathrm{mmol}^{-1}\right)$. Within a period of $10 \mathrm{~min}, 100 \mu \mathrm{l}$ volumes were rapidly filtered through $0.2 \mu \mathrm{m}$ cellulose nitrate filters. The filters were rinsed with $2 \times 2 \mathrm{ml} \mathrm{MPM} \mathrm{basal} \mathrm{salts}$ buffer, and their radioactivity measured. TCA $[15 \mu \mathrm{l}$ of a $50 \%$ (w/v) solution] was quickly added to the remaining $100 \mu \mathrm{l}$ of sample and the suspension was incubated at $80^{\circ} \mathrm{C}$ for $1 \mathrm{~h}$. The precipitated protein was subsequently filtered through a $0.2 \mu \mathrm{m}$ cellulose nitrate filter that had been pre-rinsed with $2 \mathrm{ml} 5 \%$ TCA. After post-filtration rinsing with $2 \times 2 \mathrm{ml} 5 \%$ TCA, the radioactivity on the filters was measured.

Polysaccharide content was measured by incubating $2500 \mu \mathrm{l}$ cell suspension $\left(0 \cdot 2 \mathrm{mg}\right.$ protein $\left.\mathrm{ml}^{-1}\right)$ with $2 \mu \mathrm{M}\left[{ }^{14} \mathrm{C}\right]$ glucose $\left(2.9 \mathrm{mCi} \mathrm{mmol}^{-1}\right)$ at $30^{\circ} \mathrm{C}$. At regular intervals, $200 \mu \mathrm{l}$ samples were taken and quickly mixed with $20 \mu \mathrm{l} 37 \%$ formaldehyde. A $55 \mu$ volume of this suspension was filtered through a cellulose nitrate filter and the radioactivity retained on the filter was determined in a liquid scintillation counter. The remaining cells were pelleted, washed with $1 \mathrm{ml}$ MPM basal salts buffer and pelleted again. After resuspension in $50 \mu \mathrm{l}$ of $30 \% \mathrm{KOH}$, cells were lysed at $96^{\circ} \mathrm{C}$ for $2 \mathrm{~h}$. After lysis, $150 \mu \mathrm{l}$ absolute ethanol was added to the suspension and the macromolecules precipitating in $75 \%$ ethanol were collected by centrifugation. After resuspension of the pellet in $100 \mu \mathrm{H}_{2} \mathrm{O}$, the radioactivity of a $50 \mu \mathrm{l}$ sample of the suspension was measured directly. A second $50 \mu \mathrm{l}$ sample was treated for $30 \mathrm{~min}$ with $5 \%$ (final concentration) cold TCA. The cold-TCA-insoluble fraction (nucleic acids and proteins) was collected on $0.2 \mu \mathrm{m}$ cellulose nitrate filters and its radioactivity measured. The amount of polysaccharide formed was calculated by subtracting the cold-TCAinsoluble fraction from the $75 \%$ ethanol-precipitable fraction.

Osmotic shock procedure. Cells from $50 \mathrm{ml}$ culture (approx. $65 \mu \mathrm{g}$ protein $\mathrm{ml}^{-1}$ ) were harvested by centrifugation and resuspended in $1 \mathrm{ml}$ MPM basal salts buffer. This cell suspension was rapidly diluted in $50 \mathrm{ml}$ ice-cold Milli-Q water and refrigerated for $10 \mathrm{~min}$. Shocked cells were harvested by centrifugation and stored on ice until use. The remaining 'shock fluid' was concentrated to $5 \mathrm{ml}\left(0 \cdot 1 \mathrm{mg}\right.$ protein $\left.\mathrm{ml}^{-1}\right)$ under $\mathrm{N}_{2}$ pressure by using a stirred ultrafiltration cell (Amicon) with a $10 \mathrm{kDa}$ cut-off filter (Diaflo YM10, Amicon). Binding of ${ }^{14} \mathrm{C}$ labelled substrates to concentrated shock fluids was determined by the method of Richarme \& Kepes (1983). A $100 \mu$ l volume of shock fluid was incubated with $1 \mu{ }^{14} \mathrm{C}$-labelled substrate at $30^{\circ} \mathrm{C}$ for $30 \mathrm{~min}$. Proteins were subsequently precipitated by adding $2 \mathrm{ml}$ ice-cold saturated ammonium sulphate solution. Precipitated proteins were collected on a $0.2 \mu \mathrm{m}$ cellulose nitrate filter; after post-filtration rinsing with $2 \times 2 \mathrm{ml}$ ice-cold saturated ammonium sulphate solution the radioactivity on the filters was measured. Blanks consisted of $\mathrm{L}-\left[\mathrm{U}-{ }^{14} \mathrm{C}\right]$ alanine and D-[U-14 C]glucose incubated with $100 \mu \mathrm{H}_{2} \mathrm{O}$.

Electron microscopy. Cells from $5 \mathrm{ml}$ glucose batch culture were pelleted by centrifugation and, after resuspension in $100 \mu \mathrm{l}$
MPM basal salts buffer, cells were fixed with $0 \cdot 1 \%$ glutaraldehyde. The cells were dehydrated in a graded series of ethanol solutions and embedded in Epon 812. Ultrathin sections were stained with phosphotungstic acid (PTA ; $1 \%$ ) and intracellular polysaccharide granules were viewed by transmission electron microscopy in a Philips CM10 electron microscope. Other intracellular structures were visualized by post-fixation of gluteraldehyde-fixed cells with osmium tetroxide $(1 \%)$ and staining with uranyl acetate $(1 \%)$ instead of PTA.

Chemicals. $\quad$ L-[U- $\left.{ }^{14} \mathrm{C}\right]$ Alanine $\quad\left(174 \mathrm{mCi} \mathrm{mmol}^{-1} ; \quad 6.44 \mathrm{GBq}\right.$ $\left.\mathrm{mmol}^{-1}\right)$ and $\mathrm{D}^{-}\left[\mathrm{U}_{-}{ }^{14} \mathrm{C}\right]$ glucose $\left(288 \mathrm{mCi} \mathrm{mmol}^{-1} ; 10.66 \mathrm{GBq}\right.$ $\mathrm{mmol}^{-1}$ ) were obtained from Amersham. All other chemicals were of analytical grade and obtained from commercial sources.

\section{RESULTS}

\section{Growth in batch culture}

Growth on alanine and glucose. Maximum specific growth rates for ultramicrobacterium strain RB2256 at $30{ }^{\circ} \mathrm{C}$ varied from $0.04 \pm 0.01 \mathrm{~h}^{-1}$ for growth on L-alanine to $0 \cdot 11 \pm 0 \cdot 01 \mathrm{~h}^{-1}$ for growth on peptone/yeast extract, mixed amino acids, or D-glucose plus L-alanine, and $0 \cdot 15 \pm 0 \cdot 01 \mathrm{~h}^{-1}$ for growth on D-glucose (Table 1 ).

Mixed substrate growth in batch culture on $1 \mathrm{mM} \mathrm{D}$ glucose plus $2 \mathrm{mM}$-alanine was characterized by the simultaneous utilization of the two substrates. A growth curve is presented in Fig. 1. During the first exponential phase of growth, a simultaneous consumption of glucose and alanine with a maximum specific growth rate of $0 \cdot 11 \mathrm{~h}^{-1}$ was observed. Upon depletion of glucose, the growth rate dropped to that of growth on alanine alone $\left(0.04 \mathrm{~h}^{-1}\right)$. Interestingly, substrate-dependent maximum oxygen consumption rates $\left(Q_{\mathrm{O}_{2}}^{\max }\right.$ values) indicated only limited respiration of alanine during the first exponential phase of growth $\left[Q_{\mathrm{O}_{2} \mathrm{Ala}}^{\mathrm{max}}\right.$; approx. $4 \mathrm{nmol} \mathrm{O}_{2} \mathrm{~min}^{-1}(\mathrm{mg}$ protein $\left.)^{-1}\right]$. When the glucose concentration reached micromolar levels, the respiration of alanine increased sharply (Fig. 1; Table 1). The substrate-dependent maximum oxygen consumption rates for L-alanine $\left(Q_{\mathrm{O}_{2} \mathrm{Ala}}^{\max }\right)$ and $\mathrm{D}$-glucose $\left(Q_{\mathrm{O}_{2} \mathrm{Glc}}^{\max }\right)$ during growth on alanine, glucose, and alanine plus glucose are presented in Table 1. Throughout growth on glucose plus alanine, the $Q_{\mathrm{O}_{2} \mathrm{Glc}}^{\max }$ remained essentially constant. In spite of the low $Q_{\mathrm{O}_{2} \text { Ala }}^{\max }$ during the first exponential growth phase, the occurrence of significant alanine uptake was evident (Fig. 1). Short-term uptake experiments with ${ }^{14} \mathrm{C}$-labelled alanine revealed maximum uptake rates of $42 \mathrm{nmol} \mathrm{min} \mathrm{mi}^{-1}$ (mg protein $)^{-1}$. Apparently, alanine oxidation was strongly repressed in the first growth phase.

Growth on mixed amino acids. Batch culture experiments were performed with a mixture of L-alanine, Lleucine, L-proline, L-phenylalanine, L-serine, L-histidine, L-arginine, L-glutamate, $\mathrm{L}$-aspartate and $\mathrm{L}$-glutamine, each at $1 \mathrm{mM}$. Growth occurred with a maximum specific rate of $0 \cdot 10 \mathrm{~h}^{-1}$, and all substrates were utilized simultaneously except for L-glutamate (Fig. 2). A yield of $0.21 \mathrm{~g}$ cellcarbon (g substrate-carbon) $)^{-1}$ was calculated, assuming complete utilization of proline. Proline could not be analysed by the HPLC procedure used, but it was respired by the cells. 
Table 1. Kinetic parameters for substrate uptake and utilization by ultramicrobacterium strain RB2256 during growth in batch culture on alanine, glucose or alanine plus glucose

Values are means calculated from at least five individual experiments, \pm values represent standard errors of the mean.

\begin{tabular}{|c|c|c|c|c|}
\hline & \multicolumn{4}{|c|}{ Substrate: } \\
\hline & \multirow[t]{2}{*}{ L-Alanine } & \multirow[t]{2}{*}{ D-Glucose } & \multicolumn{2}{|c|}{ L-Alanine plus D-glucose* } \\
\hline & & & $0-17 \mathrm{~h}$ & $17-32 \mathrm{~h}$ \\
\hline$\mu_{\max } \dagger$ & $0 \cdot 04 \pm 0 \cdot 01$ & $0 \cdot 15 \pm 0 \cdot 01$ & $0 \cdot 11$ & $0 \cdot 04$ \\
\hline$Q_{\mathrm{O}_{2}}^{\max }$ glucose $\ddagger$ & $<\overline{0} .01$ & $1 \overline{70}$ & $78 \pm 10$ & $80 \pm 7$ \\
\hline$Q_{\mathrm{O}_{2}}^{\max }$ alanine $\ddagger$ & 82 & 7 & $6 \pm 3$ & $59 \pm 14$ \\
\hline$V_{\max }^{2}$ glucose $\$$ & $0 \cdot 04$ & 75 & ND & ND \\
\hline$V_{\max }$ alanine $\int$ & 16 & 44 & 42 & ND \\
\hline$K_{\mathrm{t}}$ alanine $\|$ & 2 & 5 & ND & ND \\
\hline$K_{\mathrm{t}}$ glucose $\|$ & ND & $40-75$ & ND & ND \\
\hline Protein yield & $13 \pm 1$ & $32 \pm 2$ & 29 & 5 \\
\hline
\end{tabular}

ND, Not determined.

*0-17 h, first exponential phase; $17-32 \mathrm{~h}$, second exponential phase.

$\dagger$ Maximum specific growth rate $\left(h^{-1}\right)$.

$\ddagger$ Substrate-dependent maximum specific oxygen consumption rate $\left[\mathrm{nmol} \mathrm{O}_{2} \mathrm{~min}^{-1}\right.$ (mg protein) $\left.{ }^{-1}\right]$.

$\int$ Maximum specific substrate uptake rate $\left[\mathrm{nmol} \mathrm{min}^{-1}(\mathrm{mg} \text { protein })^{-1}\right]$. Values are not corrected for loss of accumulated label due to ${ }^{14} \mathrm{CO}_{2}$ formation.

\| Half-saturation constant for uptake $(\mu \mathrm{M})$.

9 Molar growth yield [g protein (mol substrate used) $\left.{ }^{-1}\right]$.

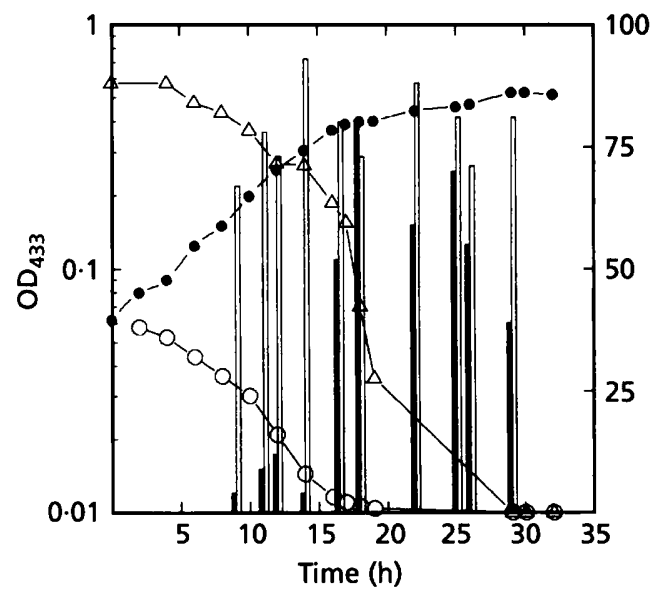

Fig. 1. Growth of ultramicrobacterium strain RB2256 on $1 \mathrm{mM}$ D-glucose plus $2 \mathrm{mM}$ L-alanine. $O, O D_{433} ; O$, glucose concentration; $\triangle$, alanine concentration. Substrate-dependent maximum specific oxygen consumption rates for the two substrates are represented by bars ( $\square$, alanine; $\square$, glucose).

During growth on L-alanine alone, cells in washed cell suspensions were able to respire not only L-alanine $\left[Q_{\mathrm{O}_{2}}^{\max }\right.$ $80 \mathrm{nmol} \mathrm{O} \min ^{-1}$ (mg protein) $\left.)^{-1}\right]$ but also L-serine (133), L-glutamine (89), L-leucine (42), L-arginine (30) and

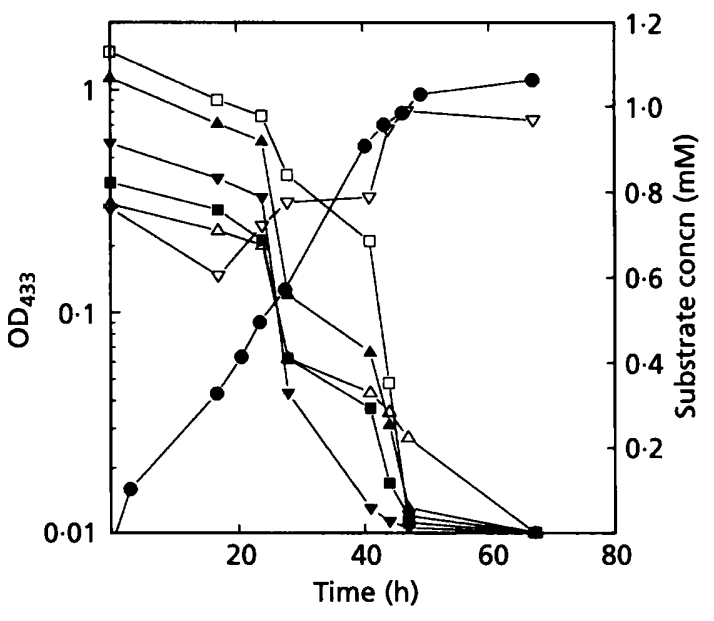

Fig. 2. Growth of ultramicrobacterium strain RB2256 on a mixture of 10 amino acids, as described in the text. For reasons of clarity only six substrates and the growth curve are displayed. $\triangle$, L-Alanine; $\boldsymbol{\Delta}$, L-phenylalanine; $\square$, L-histidine; $\nabla$, L-arginine; $\nabla$, L-glutamate; $\nabla$, L-serine; $O O_{433}$. Disappearance of L-asparagine and L-glutamine followed the L-alanine pattern, L-leucine followed the L-arginine pattern.

L-proline (12). L-Glutamate, L-phenylalanine, L-histidine and L-aspartate were also tested, but no respiration was detected. 
Table 2. Kinetic parameters for substrate uptake by ultramicrobacterium strain RB2256 during growth in chemostat culture on alanine, glucose or both substrates simultaneously

Values for kinetic constants are calculated from 10 individual uptake experiments.

\begin{tabular}{|c|c|c|c|c|c|c|c|c|c|}
\hline \multirow[t]{2}{*}{ Substrate } & \multirow{2}{*}{$\begin{array}{c}\text { Dilution } \\
\text { rate* }\end{array}$} & \multicolumn{2}{|c|}{$V_{\max } \dagger$} & \multicolumn{2}{|c|}{$q_{\mathrm{s}} \ddagger$} & \multicolumn{2}{|c|}{$K_{\mathrm{r}} \delta$} & \multicolumn{2}{|c|}{ Affinity\| } \\
\hline & & Alag & Glc & Ala & Glc & Ala & Glc & Ala & Glc \\
\hline \multirow[t]{4}{*}{ Ala } & $0 \cdot 01$ & $4(10)$ & ND & 11 & - & 1.5 & ND & 200 & ND \\
\hline & 0.02 & $7(18)$ & ND & 21 & - & $1 \cdot 8$ & ND & 300 & ND \\
\hline & $0.03(n=2)$ & $11(28)$ & 1 & 32 & - & 1.6 & 40 & 525 & 1 \\
\hline & 0.04 & $16(40)$ & 4 & 42 & - & $1 \cdot 3$ & 15 & 923 & 8 \\
\hline \multirow[t]{4}{*}{ Glc } & $0 \cdot 01$ & $19(24)$ & 22 & - & 5 & ND & 10 & ND & 66 \\
\hline & 0.03 & $29(36)$ & 43 & - & 16 & 5 & 23 & 216 & 56 \\
\hline & $0.09(n=2)$ & $25(31)$ & 71 & - & 48 & 5 & 19 & 186 & 112 \\
\hline & $0 \cdot 15$ & $24(30)$ & 75 & - & 78 & 4 & 74 & 225 & 30 \\
\hline \multirow[t]{4}{*}{ Ala plus Glc } & 0.03 & $20(25)$ & 20 & 16 & 8 & 5 & 7 & 150 & 86 \\
\hline & $0.06(n=2)$ & $25(31)$ & 27 & 32 & 16 & 6 & 18 & 155 & 45 \\
\hline & $0.09(n=2)$ & $34(43)$ & 38 & 49 & 24 & 8 & 15 & 161 & 76 \\
\hline & $0 \cdot 12$ & $44(55)$ & 60 & 62 & 31 & 9 & 24 & 183 & 75 \\
\hline
\end{tabular}

ND, Not determined.

* Dilution rate of continuous culture $\left(\mathrm{h}^{-1}\right)$.

† Maximum specific substrate uptake rate $\left.\left[\mathrm{nmol} \min ^{-1} \text { (mg protein }\right)^{-1}\right]$.

$\ddagger$ Specific substrate utilization rate $\left[\mathrm{nmol} \mathrm{min}^{-1}(\mathrm{mg} \text { protein })^{-1}\right]$.

$\int$ Half-saturation constant for substrate uptake $(\mu \mathrm{M})$.

\| Specific affinity $\left[\mathrm{l}(\mathrm{g} \text { cells })^{-1} \mathrm{~h}^{-1}\right]$ (see Schut et al., 1993). Values for alanine are corrected for losses of label due to liberation of ${ }^{14} \mathrm{CO}_{2}$ during uptake.

9 Maximum specific substrate uptake rate of alanine corrected for $\left[{ }^{14} \mathrm{C}\right]$ carbon dioxide liberation during uptake are placed between parentheses. The conversion factor used for the calculation of cellular dry weights was $0.5 \mathrm{~g}$ protein $(\mathrm{g} \text { dry weight })^{-1}$.

\section{Substrate-limited growth}

Growth in the chemostat. Molar growth yields during alanine- or glucose-limited growth in continuous culture at various dilution rates showed little variation. Yields [ $g$ protein (mol substrate used) $)^{-1}$ ] were obtained of $13.6 \pm$ $0.3\left(D 0.01-0.04 \mathrm{~h}^{-1}\right)$ and $34 \cdot 2 \pm 1 \cdot 8\left(D 0.01-0.15 \mathrm{~h}^{-1}\right)$, respectively. These values were very close to those obtained in batch culture. No significant maintenance requirement was observed at the range of dilution rates tested. During dual substrate-limited growth on glucose $(1 \mathrm{mM})$ plus alanine $(2 \mathrm{mM})$, molar growth yields of 15.9 $( \pm 2 \cdot 3) \mathrm{g}$ protein (mol substrate) ${ }^{-1}$ were determined at dilution rates of $0 \cdot 01-0 \cdot 18 \mathrm{~h}^{-1}$. This was significantly lower than the values obtained during the phase of simultaneous substrate utilization in batch culture (Table 1 , column 4). During growth on this mixture of D-glucose and L-alanine in the chemostat, both substrates were used to depletion at all dilution rates tested $\left(0 \cdot 01-0 \cdot 18 \mathrm{~h}^{-1}\right)$. Complete utilization even occurred at dilution rates much higher than the maximum specific growth rate on either of the substrates alone. The critical dilution rate for growth on the mixture of the two substrates was $0.18 \mathrm{~h}^{-1}$. This was significantly higher than the maximum specific growth rate measured during mixed substrate growth in batch culture $\left(0 \cdot 11 \mathrm{~h}^{-1}\right)$.
Short-term substrate uptake. Maximum substrate uptake rates $\left(V_{\max }\right)$, half-saturation transport constants $\left(K_{\mathrm{t}}\right)$, and specific affinities (affinity) for glucose and alanine of cells grown under single and dual substrate limitation at various growth rates are presented in Table 2. Maximum uptake rates for both substrates increased with the dilution rate. Half-saturation constants for alanine were fairly independent of the dilution rate. This resulted in an increase in the calculated specific affinity with the dilution rate for this substrate.

Cells grown under glucose limitation were able to accumulate alanine at high rates, although alanine respiration in these cells occurred at lower rates than in cells grown under alanine limitation. No significant uptake of glucose was observed in cells grown under alanine limitation (see Table 2). During growth on alanine plus glucose, the half-saturation constant $\left(K_{t}\right)$ for alanine was higher than during growth on alanine alone, while the $K_{t}$ for glucose was similar to that obtained during growth on glucose alone (Table 2).

Initial metabolism after substrate uptake. It should be noted that the measured maximum specific uptake rates for alanine ( $V_{\max }$, column 3 in Table 2 ) were lower than the measured utilization rates in growing cultures $\left(q_{\mathrm{s}}\right.$, column 4 in Table 2). It was subsequently found that 


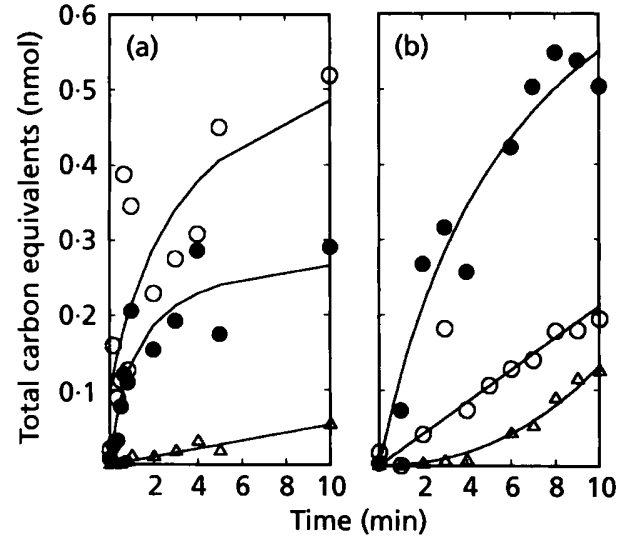

Fig. 3. Product formation from $L-\left[U^{14} \mathrm{C}\right]$ alanine accumulation in (a) alanine-limited cells and (b) glucose-limited cells of ultramicrobacterium strain RB2256. O, Liberated $\mathrm{CO}_{2} ; 0$, alanine-derived cellular material excluding protein; $\triangle$, cellular protein derived from newly accumulated alanine. Ordinate values represent the amount of total (labelled plus unlabelled) carbon equivalents in the various product fractions.

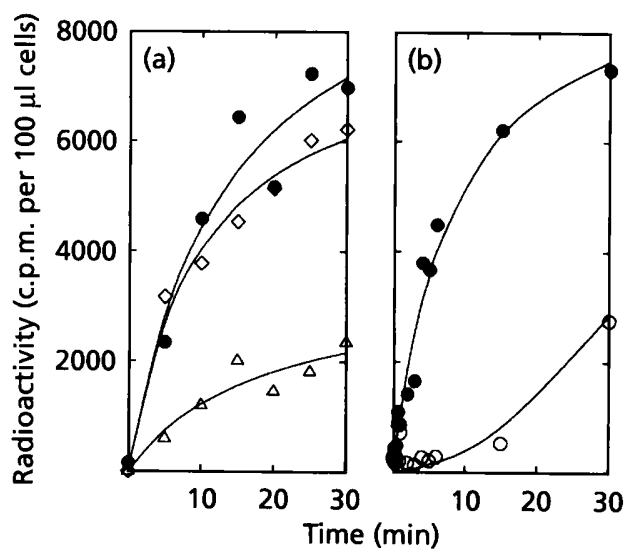

Fig. 4. Production of intracellular macromolecules (a), and liberation of carbon dioxide (b) immediately after the addition of $\mathrm{D}-\left[\mathrm{U}-{ }^{14} \mathrm{C}\right] \mathrm{glucose}$ to glucose-limited cells of ultramicrobacterium strain RB2256. Total accumulated ${ }^{14} \mathrm{C}$-label: $\diamond$, total macromolecule-associated ${ }^{14} \mathrm{C}$-label; $\triangle$, protein- and nucleic-acid-associated ${ }^{14} \mathrm{C}$-label; $\mathrm{O}$, liberated ${ }^{14} \mathrm{CO}_{2}$.

alanine uptake rates in cells grown on alanine were grossly underestimated due to rapid alanine metabolism and subsequent release of label in the form of carbon dioxide. During short-term (10 $\mathrm{min})$ uptake experiments with cells grown on alanine, approximately $60 \%$ of the total amount of alanine label taken up by the cells was liberated as carbon dioxide (Fig. 3a), while the rest of the label remained associated with cell material. Five percent of this cellular fraction was hot-TCA-insoluble and thus was associated with newly synthesized protein. Alanine uptake in glucose-limited cells was also accompanied by instantaneous ${ }^{14} \mathrm{CO}_{2}$ release. However, glucose-limited cells respired only $20 \%$ of the utilized alanine to ${ }^{14} \mathrm{CO}_{2}$ (Fig. $3 \mathrm{~b})$. Approximately $15 \%$ of the label could be recovered
Table 3. Kinetic parameters for substrate respiration by ultramicrobacterium strain RB2256 during growth in chemostat culture on alanine, glucose or both substrates simultaneously

Values for kinetic constants are calculated from 10 individual uptake experiments.

\begin{tabular}{|c|c|c|c|c|c|c|c|}
\hline \multirow[t]{2}{*}{ Substrate } & \multirow{2}{*}{$\begin{array}{l}\text { Dilution } \\
\text { rate* }\end{array}$} & \multicolumn{2}{|c|}{$q_{\mathrm{s}} \dagger$} & \multicolumn{2}{|c|}{$\boldsymbol{q}_{\mathrm{o}_{2, \mathrm{req}}} \ddagger$} & \multicolumn{2}{|c|}{$Q_{\mathrm{O}_{2}}^{\max } \mathbb{S}$} \\
\hline & & Ala & Glc & Ala & Glc & Ala & Glc \\
\hline \multirow[t]{4}{*}{ Ala } & 0.01 & 11 & - & 23 & - & $\mathrm{ND}$ & ND \\
\hline & $0 \cdot 02$ & 21 & - & 44 & - & 41 & ND \\
\hline & $0.03(n=2)$ & 32 & - & 67 & - & 60 & 1 \\
\hline & 0.04 & 42 & - & 88 & - & 82 & 5 \\
\hline \multirow[t]{4}{*}{ Glc } & 0.01 & - & 5 & - & 18 & ND & 67 \\
\hline & 0.03 & - & 16 & - & 58 & 25 & 90 \\
\hline & $0.09(n=2)$ & - & 48 & - & 173 & 68 & 105 \\
\hline & $0 \cdot 15$ & - & 78 & - & 281 & ND & 124 \\
\hline \multirow[t]{4}{*}{ Ala plus Glc } & 0.03 & 16 & 8 & 34 & 29 & 46 & 74 \\
\hline & $0 \cdot 06(n=2)$ & 32 & 16 & 67 & 58 & 63 & 82 \\
\hline & $0.09(n=2)$ & 49 & 24 & 103 & 86 & 78 & 65 \\
\hline & $0 \cdot 12$ & 62 & 31 & 130 & 112 & 69 & 81 \\
\hline
\end{tabular}

ND, Not determined.

* Dilution rate of continuous culture $\left(\mathrm{h}^{-1}\right)$.

† Specific substrate utilization rate $\left[\mathrm{nmol} \mathrm{min}^{-1}(\mathrm{mg} \text { protein })^{-1}\right]$.

$\ddagger$ Required specific oxygen utilization rate $\left[\mathrm{nmol} \mathrm{O} \mathrm{min}^{-1}(\mathrm{mg}\right.$ protein) $)^{-1}$ (see Methods).

$\S$ Substrate-dependent maximum specific oxygen consumption rate $\left[\mathrm{nmol} \mathrm{O} \mathrm{min}^{-1} \text { (mg protein) }\right)^{-1}$.

as protein within $10 \mathrm{~min}$ after addition of the labelled alanine.

The $\left[{ }^{14} \mathrm{C}\right]$ glucose that was accumulated by glucose-limited cells was immediately incorporated into cellular macromolecules (Fig. 4a). Most of the label taken up could be recovered in a $75 \%$ ethanol-precipitable fraction of a cell lysate, some $60 \%$ of which could be dissolved in $5 \%$ cold TCA. This TCA-soluble material was most probably polysaccharide, the presence of which was demonstrated by transmission electron microscopy of glucose-grown cells by phosphotungstic acid staining of ultrathin sections (see Fig. 5b). Release of ${ }^{14} \mathrm{CO}_{2}$ due to $\left[{ }^{14} \mathrm{C}\right]$ glucose metabolism by glucose-limited cells is shown in Fig. 4(b). This release was almost undetectable during the first $5 \mathrm{~min}$. Since short-term uptake kinetics were obtained from data within $30 \mathrm{~s}$ after the addition of labelled substrate, and since maximum glucose uptake rates fitted the measured substrate utilization rates in growing cultures (see Table 2), losses of label due to ${ }^{14} \mathrm{CO}_{2}$ formation were considered insignificant in the case of glucose uptake.

Maximum substrate-dependent oxygen consumption rates $\left(Q_{\mathrm{O}_{2}}^{\max }\right.$ values) for glucose and alanine at various dilution rates are presented in Table 3 . These values do 
Table 4. Effect of various inhibitory treatments on substrate uptake rate of ultramicrobacterium strain RB2256

Values are means of two independent experiments with triplicate measurements. Uptake rates are given in $\mathrm{nmol} \mathrm{min}^{-1}(\mathrm{mg}$ protein $)^{-1}$. Negative values indicate stimulation of uptake.

\begin{tabular}{|c|c|c|c|c|}
\hline \multirow{2}{*}{$\begin{array}{l}\text { Inhibitory } \\
\text { treatment }\end{array}$} & \multicolumn{2}{|c|}{ Alanine uptake } & \multicolumn{2}{|c|}{ Glucose uptake } \\
\hline & $\begin{array}{c}\text { Uptake } \\
\text { rate }\end{array}$ & $\begin{array}{c}\text { Inhibition } \\
(\%)\end{array}$ & $\begin{array}{c}\text { Uptake } \\
\text { rate }\end{array}$ & $\begin{array}{c}\text { Inhibition } \\
(\%)\end{array}$ \\
\hline None & $2 \cdot 50$ & 0 & $9 \cdot 98$ & 0 \\
\hline Osmotic shock & 0.23 & 91 & $5 \cdot 28$ & 47 \\
\hline $\mathrm{CCCP}(50 \mu \mathrm{M})$ & 0.02 & 99 & $0 \cdot 21$ & 98 \\
\hline $\operatorname{DCCD}(1 \mathrm{mM})$ & 0.03 & 99 & $0 \cdot 29$ & 97 \\
\hline $\begin{array}{l}\text { Vanadate } \\
(100 \mu \mathrm{M})\end{array}$ & $0 \cdot 29$ & 88 & ND & ND \\
\hline $\begin{array}{l}\text { Arsenate } \\
\qquad(100 \mu \mathrm{M})\end{array}$ & $2 \cdot 43$ & 3 & $7 \cdot 87$ & 21 \\
\hline $\begin{array}{c}\text { Monensin } \\
(1 \mu \mathrm{M})\end{array}$ & 1.04 & 60 & $7 \cdot 19$ & 28 \\
\hline Ethanol $(2 \%)$ & $2 \cdot 60$ & -4 & 12.69 & -27 \\
\hline
\end{tabular}

ND, Not determined.

not include the endogenous rates. In cells of ultramicrobacterium strain RB2256 grown in glucose, the endogenous respiration rates represented approximately $40 \%$ of the total respiration rates, even at very low dilution rates.

Nature of the uptake systems. In Table 4 the effect of various treatments on the uptake of alanine and glucose is presented. Both uptake systems were sensitive to osmotic shock. Inhibition of alanine uptake was nearly complete, but inactivation of the glucose uptake system was only partial. In addition, binding of $\mathrm{L}-\left[{ }^{14} \mathrm{C}\right]$ alanine and $\mathrm{D}$ $\left[{ }^{14} \mathrm{C}\right]$ glucose to proteins in concentrated shock fluids of, respectively, alanine- and glucose-grown cells was demonstrated. Binding of $\mathrm{L}^{1}\left[{ }^{14} \mathrm{C}\right]$ alanine was $587 \pm 114$ c.p.m. per filter, and binding of $\mathrm{D}-\left[{ }^{14} \mathrm{C}\right]$ glucose was $411 \pm 58$ c.p.m. per filter (means of three individual experiments \pm standard deviation). Both $\mathrm{DCCD}$, an $\mathrm{F}_{0} \mathrm{~F}_{1}$ type ATPase inhibitor, and the protonophore CCCP, completely inhibited accumulation of glucose and alanine in whole cells. Furthermore, alanine accumulation was strongly inhibited by vanadate, an analogue of phosphate, and by monensin, a sodium--proton antiporter. Glucose uptake was affected by monensin and arsenate.

Investigations of the specificity of the L-alanine uptake system (Table 5) showed that the uptake of labelled alanine was inhibited significantly by the addition of 10 amino acids other than $\mathrm{L}$-alanine. ${ }^{14} \mathrm{C}$-labelled $\mathrm{D}$-glucose uptake was affected by unlabelled D-glucose and Dglucosamine. No inhibiiton of $\mathrm{D}-\left[{ }^{14} \mathrm{C}\right]$ glucose uptake was found with galactose, sucrose, fructose, $\alpha$-methylglucose, maltose, mannitol, 2-deoxy-D-glucose, xylose, lactose, sorbitol, mannose or $N$-acetyl-D-glucosamine.

\section{DISCUSSION}

\section{Effect of glucose on utilization of alanine}

In contrast to the observations made by Law \& Button (1977) on a marine coryneform bacterium, the presence of L-alanine during dual-substrate-limited growth of ultramicrobacterium strain RB2256 did not result in lower half-saturation constants or higher specific affinities for glucose. Instead, half-saturation constants for alanine were higher $(5-9 \mu \mathrm{M})$ during dual substrate limitation than during growth on alanine alone $(1-2 \mu \mathrm{M})$. For

Table 5. Comparative inhibitory activity of various amino acids and structural analogues on the transport of $\mathrm{L}-\left[{ }^{14} \mathrm{C}\right]$ alanine in whole cells of ultramicrobacterium strain RB2256

Uptake of label was followed for $30 \mathrm{~s}$ in the presence of 10 -fold excess unlabelled substrate. Values are means calculated from at least three individual experiments, \pm values represent standard error of the mean.

\begin{tabular}{|lclc|}
\hline Substrate & $\begin{array}{c}\text { Percentage } \\
\text { inhibition }\end{array}$ & Substrate & $\begin{array}{c}\text { Percentage } \\
\text { inhibition }\end{array}$ \\
\hline L-Leucine & $95 \pm 1$ & L-Alanyl-alanine & $25 \pm 10$ \\
L-Phenylalanine & $94 \pm 1$ & L-Arginine & $5 \pm 2$ \\
L-Isoleucine & $94 \pm 1$ & L-Threonine & $4 \pm 11$ \\
L-Methionine & $93 \pm 1$ & L-Glutamate & $3 \pm 1$ \\
4-Aminobutyric acid & $91 \pm 2$ & D-Alanine & $3 \pm 1$ \\
L-Tryptophan & $91 \pm 2$ & L-Serine & $3 \pm 1$ \\
L-Alanine & $90 \pm 1$ & L-Aspartate & $3 \pm 0$ \\
L-Glycine & $61 \pm 2$ & L-Glutamine & $2 \pm 1$ \\
L-Histidine & $60 \pm 4$ & L-Proline & $1 \pm 1$ \\
L-Asparagine & $59 \pm 2$ & $\alpha$-Aminoisobutyric acid & 0 \\
L-Lysine & $53 \pm 8$ & & \\
\hline
\end{tabular}


comparable alanine utilization rates, this effect can best be observed at dilution rates of $0.03 \mathrm{~h}^{-1}$ and $0.06 \mathrm{~h}^{-1}$ for growth on alanine and alanine plus glucose, respectively (Table 2). The increase in half-saturation constant (from 1.6 to $6 \mu \mathrm{M}$ ) does not coincide with a significant increase

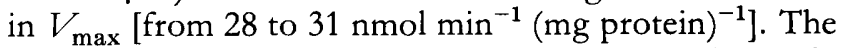
result is a considerable decrease in the calculated specific affinity for alanine.

According to a molecular kinetic model proposed by Button (1991, 1993), high half-saturation constants $\left(K_{\mathrm{t}}\right.$ values) for whole-cell substrate uptake can be attributed to high ratios of the rate-limiting metabolic enzyme concentration relative to the membrane transporter concentration $\left(K_{\mathrm{t}}\right.$, limiting enzyme/transporter content). According to this model, maximum uptake and utilization rates are determined by the absolute quantity of both the limiting enzyme and the transporter ( $V_{\max }$, limiting enzyme $\times$ transporter content) and both components can independently accelerate the pathway flux. When applying this model to the observations on strain RB2256, the increase in $K_{\mathrm{t}}$ at relatively constant $V_{\max }$ may result from an increase in internal enzyme concentration with a concomitant and proportional decrease in transporter concentration. The idea that the metabolic enzyme activity in strain RB2256 increases in the presence of glucose is suggested by two observations. (i) During dual-substratelimited growth, alanine utilization occurred at rates that were almost $50 \%$ higher than the maximum attainable rate during growth on alanine alone $\left(q_{\mathrm{s}}\right.$ values in Table 2$)$. Such a stimulation of the utilization rate of an amino acid (glutamate) in the presence of glucose was also reported for Caulobacter crescentus (Poindexter, 1987). (ii) The maximum specific growth rate of cells cultured under dual substrate limitation was significantly higher than the maximum attainable rates on the individual substrates. According to the model of Button (1991, 1993), the specific substrate affinity $\left(a_{\mathrm{A}}^{0}\right)$ is largely determined by the transporter content. The decrease in specific affinity for alanine during dual substrate limitation may thus reflect a decreased alanine transporter activity. Since little change occurs in the actual metabolic flux (compare $D 0.03 \mathrm{~h}^{-1}$ with an L-alanine concentration in the reservoir $\left(S_{\mathrm{r}}^{\text {Ala }}\right)$ $4 \mathrm{mM}$ and $D 0.06 \mathrm{~h}^{-1}$ with $S_{\mathrm{r}}^{\text {Ala }} 2 \mathrm{mM}$, for single and dual substrate limitation, respectively) an increase in $K_{\mathrm{t}}$ is to be expected as a result of the presence of glucose via a decrease in transporter activity. More detailed physiological investigations are needed in order to substantiate this conclusion.

\section{Glucose metabolism and endogenous respiration}

As shown in Table 3 , the $Q_{\mathrm{O}_{2}}^{\max }$ values for glucose at high dilution rates are considerably lower than the rates required for complete oxidation of utilized substrate $\left(q_{\mathrm{O}_{2}}\right.$, req $)$. The high endogenous oxygen consumption rate in these cells, often representing approximately $40-50 \%$ of the total oxygen consumption rate, is primarily responsible for this discrepancy and suggests the presence of large amounts of intracellular respirable compounds. The immediate incorporation of glucose into $75 \%$ ethanol-precipitable polysaccharide was demonstrated in
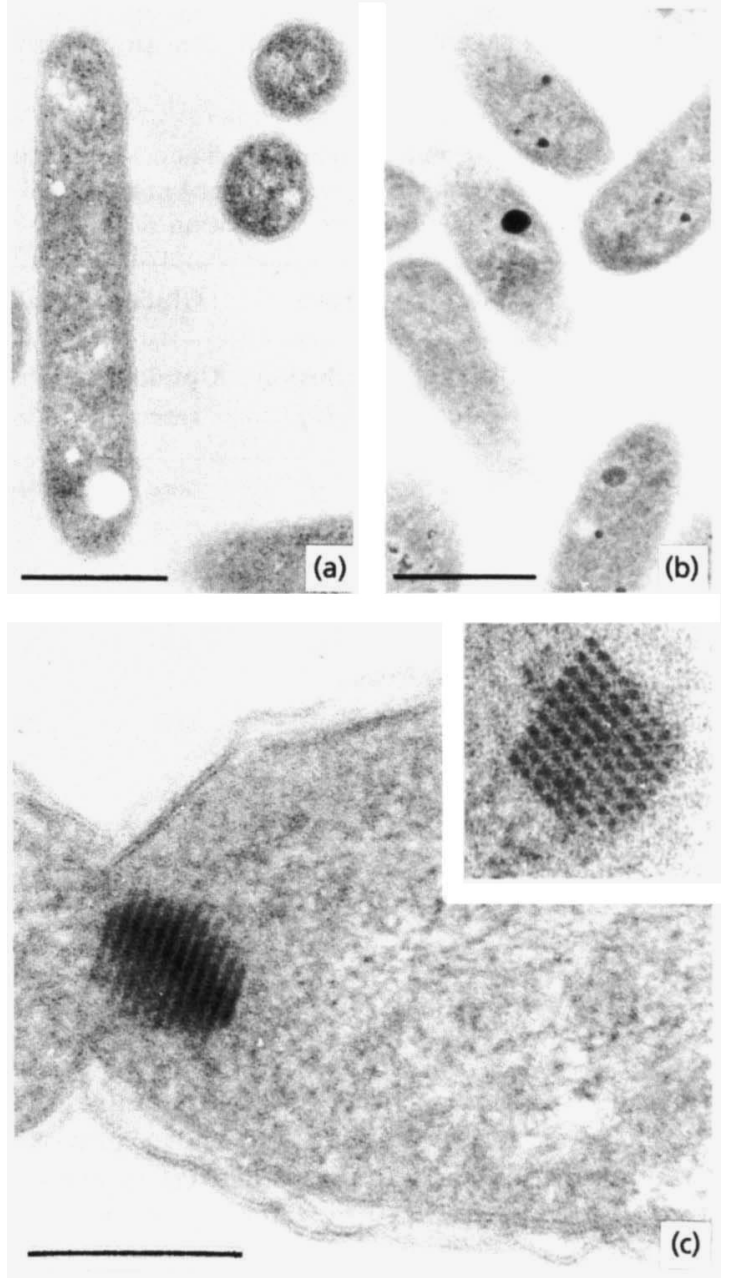

Fig. 5. Transmission electron micrographs of glucose-grown cells of ultramicrobacterium strain RB2256. Chemostat-grown cells $\left(D 0.04 \mathrm{~h}^{-1}\right)$ stained with uranyl acetate (a) and with phosphotungstic acid showing polysaccharide granules (b). (c) Glucose-grown cells from the exponential phase stained with uranyl acetate showing intracellular crystalline structures. Inset shows a similar structure viewed from a different angle. Bars, $0.5 \mu \mathrm{m}$ (a and b); $0.1 \mu \mathrm{m}$ (c).

washed cell suspensions of glucose-limited cells (Fig. 4a). This indicates that pathways for the production of storage material are expressed even during glucose-limited growth. Relatively slow liberation of ${ }^{14} \mathrm{CO}_{2}$ after utilization of universally labelled D- $\left[{ }^{14} \mathrm{C}\right]$ glucose (Fig. 4b) reflects slow equilibration of intracellular pools. This also indicates that newly accumulated glucose is not immediately respired but captured in an intracellular pool. The respiration of endogenous-glucose-derived polymeric storage material represents an important process in glucose utilization by strain RB2256. Intracellular storage of polysaccharides in glucose-grown cells was confirmed by using transmission electron microscopy (Fig. 5). Studies on endogenous respiration and the presence of this polysaccharide material in relation to the starvation survival of strain RB2256 will be published elsewhere. 
Large crystalline structures in glucose-grown cells from batch and continuous cultures of strain RB2256 were observed in electron micrographs (Fig. 5c). The exact growth condition that results in the formation of these structures could not be determined. The nature of the crystals is probably protein but their function is at present unknown.

\section{Nature of the substrate uptake systems}

The glucose uptake system in strain RB2256 is inducible as indicated by the absence of glucose accumulation in alanine-grown cells. On the other hand, the alanine uptake system in this strain is constitutively expressed. Constitutive transporters allow effective scavenging of intermittently occurring substrates (Poindexter, 1981). In the natural environment with complex mixtures of multiple substrates, the possession of constitutive uptake systems with a low substrate specificity increases the effective extracellular substrate availability and may thus result in an increase in actual nutrient uptake. $\mathrm{L}-\left[{ }^{\mathbf{1 4}} \mathrm{C}\right]$ Alanine uptake in strain RB2256 was inhibited $90-95 \%$ by a 10-fold higher concentration of unlabelled L-alanine, L-leucine, L-phenylalanine, L-isoleucine, L-methionine, 4-aminobutyric acid or L-tryptophan. This implies that these substrates share a common transport system. L-Glycine, L-histidine, L-asparagine, L-lysine and the dipeptide L-alanyl-alanine inhibited $\mathrm{L}-\left[{ }^{14} \mathrm{C}\right]$ alanine uptake to a lesser extent $(25-61 \%)$, but the possibility that these substrates are also accumulated via the alanine transport system cannot be excluded. Based on substrate specificity and kinetic parameters, the L-alanine transport system in strain RB2256 shows no relatedness to the LIV system of Alteromonas baloplanktis $\left[K_{\mathrm{t}} 190 \mu \mathrm{M}, V_{\max }\right.$, $20.8 \mathrm{nmol} \mathrm{min}^{-1}\left(\mathrm{mg} \mathrm{dry} \mathrm{wt}^{-1}\right]$ (Fein \& MacLeod, 1975), or to the LIV-I system of Escherichia coli (Rahmanian et al., 1973) which translocates the branchedchain amino acids L-alanine, $\mathrm{L}$-threonine and $\mathrm{L}$-serine. In strain RB2256, threonine and serine are not transported via the alanine transport system. There is also no similarity with the binding-protein-dependent alanine transport system in Rbodobacter sphaeroides (Abee et al., 1989) $\left[K_{\mathrm{t}}\right.$ $4.2 \mu \mathrm{M}, V_{\max }, 12.9 \mathrm{nmol} \min ^{-1}$ (mg protein) $\left.)^{-1}\right]$, which transports aminoisobutyric acid equally well. With respect to the broad specificity of the system in RB2256, most similarity is observed with the 'general' amino acid permease in Caulobacter crescentus (Ferber \& Ely, 1982). When compared to other L-alanine-transporting permeases, the system in strain RB2256 exhibits a very broad specificity, a high $V_{\max }$ value, and a low half-saturation constant. The observation that mixed amino acids are accumulated with high specific affinity in this organism (Schut et al., 1993) may partly be explained by the possession of this low specificity, high affinity uptake system. In contrast, the glucose uptake system in strain RB2256 shows a very narrow substrate specificity.

The uptake systems of both alanine and glucose in strain RB2256 exhibit osmotic shock sensitivity. Binding of alanine and of glucose to proteins in concentrated shock fluids of alanine- and glucose-grown cells was also demonstrated. Both these observations indicate the presence of binding-protein-dependent transport systems. The uptake of both alanine and glucose was effectively blocked by DCCD and alanine accumulation was also inhibited by vanadate, indicative of the direct involvement of high energy phosphate bonds in transport. It has been shown that ATP can interact with membrane-bound components of binding-protein-dependent transport systems (Hobson et al., 1984) and it seems likely that ATP is the driving force for this type of transport (Bakker et al., 1987). Although not determined in this study, the inhibition of uptake in strain RB2256 in the presence of CCCP and monensin may have resulted from an indirect loss of ATP-synthesizing abilities due to a change in the transmembrane ion gradient.

Glucose uptake is inhibited by $50 \%$ when cells are osmotically shocked, implying either that expulsion of binding proteins from the periplasmic space is not complete or that other glucose uptake systems are present. This latter hypothesis is supported by the fact that the half-saturation constants for glucose uptake are considerably higher than the values of $0 \cdot 4-2 \cdot 0 \mu \mathrm{M}$ characteristic of binding-protein-dependent transport systems (Furlong, 1987). Group-translocation-mediated uptake of glucose by the phosphoenolpyruvate-dependent sugar phosphotransferase system (PTS) was not detected in strain RB2256 (assayed by the method of Robillard \& Blaauw, 1987; data not presented). Whether strain RB2256 possesses a secondary (proton-motive-forcedriven) glucose transport system remains to be determined.

Although they are energetically more costly than secondary transport systems, binding-protein-dependent transporters are excellent substrate-capturing systems. This type of transport system is able to concentrate substrates against $10^{5}$-fold gradients and they are unidirectional, which makes them very suitable for substrate transport under oligotrophic conditions (Konings \& Veldkamp, 1983). The effectiveness of this type of transport system is illustrated by the very high specific affinities for alanine. As far as we know, the value of $923 \mathrm{l}$ (g cells $)^{-1} \mathrm{~h}^{-1}$ at a dilution rate of $0.04 \mathrm{~h}^{-1}$ is the highest ever reported for this substrate (see also Schut et al., 1993). The values reported in a previous paper (Schut t al., 1993) were not corrected for carbon dioxide formation during substrate accumulation and therefore do not represent true uptake rates.

\section{Simultaneous substrate utilization}

When organisms are supplied with millimolar concentrations of a mixture of substrates that serve the same physiological function, i.e. carbon or nitrogen source, a diauxic or sequential utilization is often observed (Harder \& Dijkhuizen, 1982, 1983; Magasanik \& Neidhardt, 1987). It is now well established that the simultaneous utilization of 'diauxic' substrates occurs only at growthrate-limiting (micromolar) concentrations, when uptake and utilization pathways of the second substrate become 
derepressed (Egli et al., 1983, 1986). With strain RB2256, we observed simultaneous utilization of alanine and glucose under nutrient-sufficient conditions in batch culture. Although alanine oxidation was repressed by high glucose concentrations in these cultures, uptake of alanine continued and it may thus be concluded that alanine was assimilated into cell material. Under dual substrate limitation in continuous culture, the situation is less clear since the potential respiratory utilization of alanine (see $Q_{\mathrm{O}_{2}}^{\max }$ values) is fully expressed in the presence of glucose. The extent of assimilation of alanine in such chemostat cultures has not been further investigated.

Strain RB2256 is a bacterial strain of marine origin with the low cell volume and low DNA content that is characteristic of indigenous marine ultramicrobacteria. The organism is capable of capturing low concentrations of multiple substrates, specifically amino acids, simultaneously, and regulates the utilization pathways of accumulated substrates. Since the cell volume of this strain is only $0.06 \mu \mathrm{m}^{3}$, substrate requirements are low relative to marine isolates of larger cell volume. The reported specific substrate affinity for alanine at ambient substrate concentrations of $10 \mathrm{nM}$ alanine would result in generation times in situ of about $60 \mathrm{~d}$. However, at ambient dissolved free amino acid concentrations of $200 \mathrm{nM}$, simultaneous uptake of multiple amino acids via the constitutive, low specificity alanine transporter would reduce this generation time to $3 \mathrm{~d}$.

\section{ACKNOWLEDGEMENTS}

The authors would like to thank the research group of Professor W. N. Konings for support with the radioactivity uptake experiments, and K. Sjollema for electron microscopy. Funding for this project was partly provided by The Netherlands Institute for Sea Research.

\section{REFERENCES}

Abee, T., van der Wal, F.-J., Hellingwerf, K. J. \& Konings, W. N. (1989). Binding-protein-dependent alanine transport in Rbodobacter sphaeroides is regulated by the internal $\mathrm{pH}$. J Bacteriol 171, 5148-5154.

Akagi, Y. \& Taga, N. (1980). Uptake of D-glucose and L-proline by oligotrophic and heterotrophic marine bacteria. Can J Microbiol 26, 454-459.

Ammerman, J. W., Fuhrman, J. A., Hagström, Å. \& Azam, F. (1984). Bacterioplankton growth in seawater. I. Growth kinetics and cellular characteristics in seawater cultures. Mar Ecol Prog Ser 18, 31-39.

Bakker, E. P., Borchard, A., Michels, M., Altendorf, K. \& Siebers, M. (1987). High-affinity potassium uptake system in Bacillus acidocaldarius showing immunological cross-reactivity with the Kdp system from Escherichia coli. J Bacteriol 169, 4342-4348.

Billen, G., Joris, C., Wijnant, J. \& Gillain, G. (1980). Concentration and microbiological utilization of small organic molecules in the Scheldt estuary, the Belgian coastal zone of the North Sea and the English Channel. Estuarine Coastal Mar Sci 11, 279-294.

Button, D. K. (1991). Biochemical basis for whole-cell uptake kinetics: specific affinity, oligotrophic capacity, and the meaning of the Michaelis constant. Appl Environ Microbiol 57, 2033-2038.

Button, D. K. (1993). Nutrient-limited microbial growth kinetics: overview and recent advances. Antonie Leeunenboek 63, 225-235.
Carlucci, A. F. \& Williams, P. M. (1978). Simulated in situ growth rates of pelagic marine bacteria. Naturwissenschaften 65, 541-542.

Egli, Th., Lindley, N. D. \& Quayle, J.R. (1983). Regulation of enzyme synthesis and variation of residual methanol concentration during carbon-limited growth of Kloeckera sp. 2201 on mixtures of methanol and glucose. J Gen Microbiol 129, 1269-1281.

Egli, Th., Bosshard, C. \& Hamer, G. (1986). Simultaneous utilization of methanol-glucose mixtures by Hansenula polymorpha in chemostat: influence of dilution rate and mixture composition on utilization pattern. Biotechnol Bioeng 28, 1735-1741.

Eguchi, M. \& Ishida, Y. (1990). Oligotrophic properties of heterotrophic bacteria and in situ heterotrophic activity in pelagic seawaters. FEMS Microbiol Ecol 73, 23-30.

Fein, J. E. \& MacLeod, R. A. (1975). Characterization of neutral amino acid transport in a marine pseudomonad. J Bacteriol 124, $1177-1190$.

Ferber, D. M. \& Ely, B. (1982). Resistance to amino acid inhibition in Caulobacter crescentus. Mol \& Gen Genet 187, 446-452.

Ferguson, R. L., Buckley, E. N. \& Palumbo, A. V. (1984). Response of bacterioplankton to differential filtration and confinement. Appl Environ Microbiol 47, 49-55.

Furlong, C. E. (1987). Osmotic-shock-sensitive transport systems. In Escherichia coli and Salmonella typhimurium, pp. 768-796. Edited by F. C. Neidhardt, J. L. Ingraham, K. Brooks Low, B. Magasanik, M. Schaechter \& H. E. Umbarger. Washington, DC: American Society for Microbiology.

Geesey, G. G. \& Morita, Y. R. (1979). Capture of arginine at low concentrations by a marine psychrophilic bacterium. Appl Environ Microbiol 38, 1092-1097.

Gottschal, J. C., Harder, W. \& Prins, R. A. (1992). Principles of enrichment, isolation, cultivation and preservation of bacteria. In The Prokaryotes, pp. 149-196. Edited by A. Balows, H. G. Trüper, M. Dworkin, W. Harder \& K.-H. Schleifer. New York: SpringerVerlag.

Hagström, Å., Ammerman, J. W., Henrichs, S. \& Azam, F. (1984). Bacterioplankton growth in seawater. II. Organic matter utilization during steady-state growth in seawater cultures. Mar Ecol Prog Ser $18,41-48$.

Hamilton, R. D., Morgan, K. M. \& Strickland, J. D. H. (1966). The glucose uptake kinetics of some marine bacteria. Can J Microbiol 21, 995-1003.

Harder, W. \& Dijkhuizen, L. (1982). Strategies of mixed substrate utilization in microorganisms. Philos Trans R Soc Lond B Biol Sci 297, 459-480.

Harder, W. \& Dijkhuizen, L. (1983). Physiological responses to nutrient limitation. Annu Rev Microbiol 37, 1-23.

Hobbie, J. E. \& Crawford, C. C. (1969). Respiration corrections for bacterial uptake of dissolved organic compounds in natural waters. Limnol Oceanogr 14, 528-532.

Hobson, A. C., Weatherwax, R. \& Ames, G. F.-L. (1984). ATPbinding sites in the membrane components of histidine permease, a periplasmic transport system. Proc Natl Acad Sci US A 81, 7333-7337.

Jannasch, H. W. (1967). Growth of marine bacteria in limiting concentrations of organic carbon in seawater. Limnol Oceanogr 12, 264-271.

Karl, D. M. (1979). Measurement of microbial activity and growth in the ocean by rates of stable ribonucleic acid synthesis. Appl Environ Microbiol 38, 850-860.

Konings, W. N. \& Veldkamp, H. (1983). Energy transduction and solute transport mechanisms in relation to environments occupied 
by microorganisms. In: Microbes in their Natural Environments (Society for General Microbiology Symposium 34), pp. 153-186. Edited by J. H. Slater, R. Whittenbury \& J. W. T. Wimpenny. Cambridge: Cambridge University Press.

Law, A. T. \& Button, D. K. (1977). Multiple-carbon-source-limited growth kinetics of a marine coryneform bacterium. J Bacteriol 129, 115-123.

Li, W. K. W. \& Dickie, P. M. (1985). Growth of bacteria in seawater filtered through $0.2 \mu \mathrm{m}$ Nuclepore membranes: implications for dilution experiments. Mar Ecol Prog Ser 26, 245-252.

Magasanik, B. \& Neidhardt, F. C. (1987). Regulation of carbon and nitrogen utilization. In Escherichia coli and Salmonella typhimurium, pp. 1318-1325. Edited by F. C. Neidhardt, J. L. Ingraham, K. Brooks Low, B. Magasanik, M. Schaechter \& H. E. Umbarger. Washington, DC: American Society for Microbiology.

Morita, R. Y. (1988). Bioavailability of energy and its relationship to growth and starvation survival in nature. Can J Microbiol 34, 436-441.

Morita, R. Y. (1990). The starvation-survival state of microorganisms in nature and its relationship to the bioavailable energy. Experientia 46, 813-817.

Münter, U. (1993). Concentrations and fluxes of organic carbon substrates in the aquatic environment. Antonie Leeuwenboek 63, 243-274.

Nissen, H., Nissen, P. \& Azam, F. (1984). Multiphasic uptake of D-glucose by an oligotrophic marine bacterium. Mar Ecol Prog Ser 16, 155-160.

Poindexter, J. S. (1981). Oligotrophy. Fast and famine existence. Adv Microb Ecol 5, 63-89.

Poindexter, J. S. (1987). Bacterial responses to nutrient limitation. In: Ecology of Microbial Communities (Society for General Microbiology Symposium 41), pp. 283-317. Edited by M. Fletcher, T. R.

G. Gray \& J. G. Jones. Cambridge: Cambridge University Press.
Poulet, S. A., Martin-Jézéquel, V. \& Head, R. N. (1984). Distribution of dissolved free amino acids in the Ushant front region. Mar Ecol Prog Ser 18, 49-55.

Rahmanian, M., Claus, D. R. \& Oxender, D. L. (1973). Multiplicity of leucine transport systems in Escherichia coli K-12. J Bacteriol 116, 1258-1266.

Richarme, G. \& Kepes, A. (1983). Study of binding protein-ligand interaction by ammonium sulphate-assisted adsorption on cellulose esters filters. Biochim Biophys Acta 742, 16-24.

Robillard, G. T. \& Blaauw, M. (1987). Enzyme II of the Escherichia coli phosphoenolpyruvate dependent phosphotransferase system: protein-protein and protein-phospholipid interaction. Biochemistry 26, 5796-5803.

Schut, F., de Vries, E. J., Gottschal, J. C., Robertson, B. R., Harder, W., Prins, R. A. \& Button, D. K. (1993). Isolation of typical marine bacteria by dilution culture: growth, maintenance, and characteristics of isolates under laboratory conditions. Appl Environ Microbiol 59, 2150-2160.

Sieburth, J. McN., Johnson, K. M., Burney, C. M. \& Lavoie, D. M. (1977). Estimation of in situ rates of heterotrophy using diurnal changes in dissolved organic matter and growth rates of picoplankton in diffusion culture. Helgol Wiss Meeresunters 30, 565 -574.

Upton, A. C. \& Nedwell, D. B. (1989). Nutritional flexibility of oligotrophic and copiotrophic Antarctic bacteria with respect to organic substrates. FEMS Microbiol Ecol 62, 1-6.

Yabuuchi, E., Yano, I., Oyaizu, H., Hashimoto, Y., Ezaki, T. \& Yamamoto, H. (1990). Proposals of Sphingomonas paucimobilis gen. nov. and comb. nov., Spbingomonas parapaucimobilis sp. nov., Sphingomonas yanoikuyae sp. nov., Sphingomonas adhaesiva sp. nov., Sphingomonas capsulata comb. nov., and two genospecies of the genus Sphingomonas. Microbiol Immunol 34, 99-110.

Received 17 May 1994; revised 10 October 1994; accepted 19 October 1994. 